\title{
THE RATE OF FILTRATION THROUGH THE CAPILLARY WALLS AS MEASURED BY ITHE PRESSURE PLETHYSMOGRAPH. OB- SERVATIONS ON CONTROL SUBJECTS AND ON PATIENTS WITH INTRAHEPATIC DISEASE, THYROTOXICOSIS, AND MYXEDEMA
}

\author{
By BENJAMIN V. WHITE 1 aNd CHESTER M. JONES \\ (From the Medical Clinic of the Massachusetts General Hospital and the Department of \\ Medicine of the Harvard Medical School, Boston)
}

(Received for publication September 16, 1938)

The frequent occurrence of telangiectasis, ecchymoses, bleeding tendencies, ascites, and peripheral edema in the various types of intrahepatic disease suggested the value of a study of the permeability of the capillaries in such subjects. The traumatic methods of estimating capillary permeability $(1,2,3)$ appeared to show a too wide range of normal values. The dye injection method (4) was not available for human use. The use of the plethysmograph was therefore elected. It was desired to obtain evidence, if possible, as to whether peripheral edema in particular, in serious hepatic disease, resulted in part from increased capillary permeability.

Landis and Gibbon (5) modified the pressure plethysmograph of Krogh, Landis, and Turner (6) so as to eliminate errors caused by differences in the degree of contraction of blood vessels during the volumetric readings. This they accomplished by exerting a pressure of $200 \mathrm{~mm}$. $\mathrm{Hg}$ upon the fluid in the plethysmograph during the reading periods. Such a pressure was adequate to compress the entire vascular tree and to record with a moderate degree of accuracy small changes in the amount of interstitial fluid. Readings of reduced arm volume (under pressure of $200 \mathrm{~mm}$. $\mathrm{Hg}$ ) were made before and after obstruction to the venous outflow from the arm, and the rate of fluid filtered was calculated from the increase in reduced arm, volume and the volume of the arm which had actually been in the plethysmograph.

Landis and Gibbon's studies were confined to two normal male subjects, so that the filtration rate was not complicated by depleted serum protein and low colloid osmotic pressure. Smirk (7) also approached the problem of capillary permeability by the measurement of changes in arm volume before and after venous obstruction. $\mathrm{He}$

\footnotetext{
1 Jeffrey Richardson Fellow-Harvard Medical School.
}

made determinations in patients with the nephrosis syndrome and with hepatic insufficiency, in both of which conditions the serum proteins were depleted. Hence the pressure in the cuff which occluded the venous outflow was not set at an arbitrary absolute figure but was regulated so as to be greater by a constant amount than the colloid osmotic pressure of the serum. The colloid osmotic pressure was measured directly by the use of the osmometer of Verney (8).

Starling (9) showed that the colloid osmotic pressure of the human serum was roughly proportional to the concentration of protein which it contained. Govaerts (10) subsequently concluded that one gram per cent of serum albumin exerted a colloid osmotic pressure of $7.54 \mathrm{~cm}$. $\mathrm{H}_{2} \mathrm{O}$ while one gram per cent of serum globulin exerted a colloid osmotic pressure of $1.95 \mathrm{~cm}$. $\mathrm{H}_{2} \mathrm{O}$. Although some justified criticism of these figures has appeared, Wies and Peters (11) made an empirical study of human sera which tended to confirm the validity of estimates of colloid osmotic pressure based on the concentrations of different protein fractions. Wies and Peters found that estimates based upon the total protein alone were less accurate than those based upon albumin and globulin separately. They found, however, that estimates of colloid osmotic pressure based upon specific factors for albumin and globulin were inclined to be low for protein levels in the higher range of normal. Hence they prepared a formula from which they found that more accurate estimations could be made. (See Method.)

In this study a combination of the methods of Landis and Gibbon and of Smirk was employed. The 'pressure plethysmograph was used, but the obstructing venous pressure was in every case greater by a constant amount than the colloid 
osmotic pressure of the serum. The colloid osmotic pressure of the serum was estimated from the concentrations of 'serum albumin and serum globulin by the use of the formula of Wies and Peters to be described below.

Studies were made on a group of normal controls largely recruited from young doctors, technicians, and secretaries about the hospital, and on a group of patients with severe liver disease. This latter group included patients with severe secondary biliary cirrhosis, some of whom were observed both before and after surgical relief of the obstruction, patients with toxic cirrhosis (Laennec's cirrhosis), and one patient with subacute yellow atrophy. Many of these persons had frank evidence of peripheral edema, ascites, ecchymoses, telangiectasis or bleeding tendencies.
Observations were also made on a series of eight patients with frank hyperthyroidism, at the time of admission to the hospital, after the effect of iodine therapy, and one month or more postoperatively. A series of three patients with myxedema was studied both before and after thyroid therapy. Isolated observations were made on one patient with acute nephritis with edema (Subject 35 ), on one patient with urticaria (Subject 36) during a menstrual period and between menstrual periods, and on one patient with peptic ulcer (Subject 37). This last patient was studied twice, once when his blood vitamin $C$ level was $0.1 \mathrm{mgm}$. per cent and subsequently when it had been elevated by intravenous therapy to $0.7 \mathrm{mgm}$. per cent. These three patients are included with the control group in Figure 1.

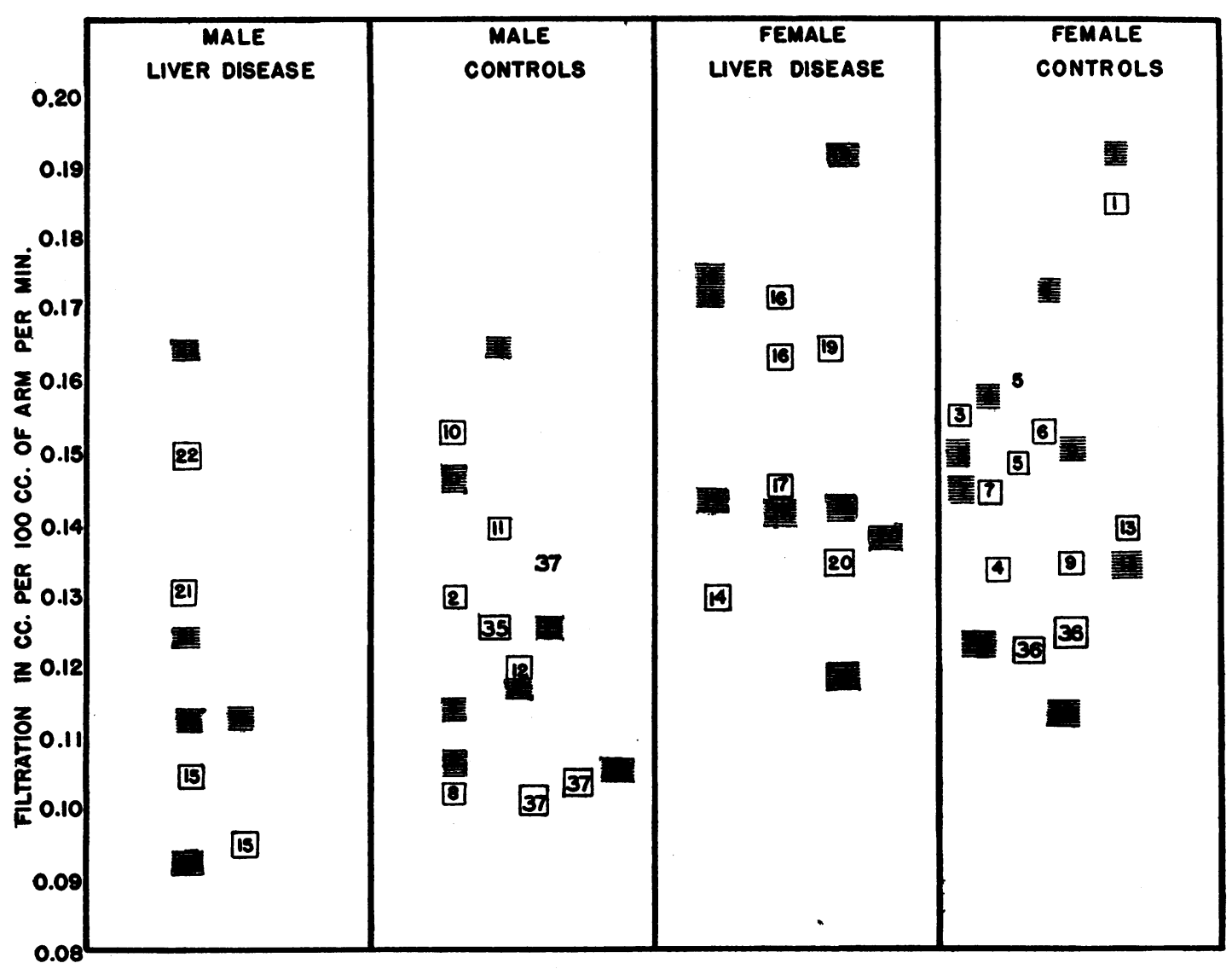

Fig. 1. Rates of Filtration through the Capinlary Wall in Control Subjects and in Pattents With Intrahepatic Disease

The number of patients correspond with those in Tables I and II. Right arm readings are recorded in cross hatched squares, left arm readings in hollow squares. Note that the upper and lower limits observed in male and female control subjects are not appreciably exceeded in the corresponding groups of patients with liver disease. 


\section{METHOD}

The operation of the pressure plethysmograph has been adequately described by Landis and Gibbon (5).

Repeated determinations of the reduced arm volume were made at 10-minute intervals until successive determinations checked within $1 \mathrm{~cm}$. A cufi which had been placed upon the upper arm was then inflated for a period of 10 minutes at a pressure which would raise the hydrostatic pressure of the veins within the plethysmograph to a point exactly $20 \mathrm{~cm} . \mathrm{H}_{2} \mathrm{O}$ above the colloid osmotic pressure of the serum. The method of calculating the culf pressure is described below.

After the 10-minute period of venous congestion, a final determination of reduced arm volume was made. The difference between this final determination and the last determination previous to inflation of the cuff represented the actual amount of fluid which had filtered through the capillary walls. If divided by the number of cubic centimeters of arm volume in the plethysmograph, it represented the fraction of a cubic centimeter filtered per cubic centimeter of arm in 10 minutes. To conform with the system of recording used by Landis and Gibbon, the decimal point was moved one space to the right, so as to represent the amount of fluid filtered per $100 \mathrm{cc}$. of arm in one minute. This figure was used throughout the illustrations.

With two exceptions all readings were checked by successive determinations on both arms. In most instances the readings of the two arms were moderately close, considering the sources of error imposed by the technique. In several instances the two arms did not check. In those cases the arm which was presumed to be wrong was restudied subsequently. If it then checked with the expected reading, no further study was made. If it failed to check, the first arm was also repeated. In the case of Patient 29 with thyrotoxicosis there was a wide discrepancy between the readings of the two arms. In this instance, before operation, the left arm was studied three times and the right arm twice. The checks in this case were moderately close and always showed the left arm to have a much lower rate than the right. The rates of the two arms were, however, usually moderately close and served as a check on the technique.

The methods followed in this study are identical with those of Landis and Gibbon except in the following details :

1. Temperature. Observations were made in a room which was maintained at almost constant temperature throughout each determination. Fluctuations of more than $1^{\circ} \mathrm{C}$. were unusual. Landis and Gibbon found that fluctuations in room temperature affected their results but little. The plethysmograph temperature was maintained between $34.5^{\circ}$ and $35.5^{\circ} \mathrm{C}$. throughout all readings. Landis and Gibbon found the rate of filtration to vary proportionately with the temperature of the plethysmograph, the filtration rate at $45^{\circ} \mathrm{C}$. being roughly twice that observed at $15^{\circ}$. For the purposes of this study $35^{\circ}$ C. was chosen because it was easy to maintain and was most comfortable for the patient.
2. Pressure in the venous cuff. Inasmuch as the forearm was in a vertical position, the cuff about the brachium was lower than the plethysmograph by a considerable distance. In order to maintain the desired hydrostatic pressure within the veins of the forearm it was necessary to add to the pressure within the cuff enough additional pressure to offset the elevation of the plethysmograph. Landis and Gibbon added a number of centimeters of water equal to the distance from the core of the brachium to the top of the plethysmograph. For convenience, the same points of reference were used in this study. The number of centimeters added for this purpose varied from 19 to 22 . In Tables I, II, and III, this hydrostatic factor is omitted and only the effective pressure within the plethysmograph is recorded.

In order to produce filtration, Smirk (7) added $20 \mathrm{~cm}$. $\mathrm{H}_{2} \mathrm{O}$ to the colloid osmotic pressure of the serum. Since the arm was in the horizontal position, the hydrostatic factor was not added. In the present study, the hydrostatic factor (usually 20 to 22 ) was added to the constant factor (20) and the sum of these two was added to the colloid osmotic pressure of the serum.

The colloid osmotic pressure of the serum was calculated from the fifth formula of Wies and Peters:

$$
\mathrm{COP}=A / W \times 60.9+G / W \times 22.9-50,
$$

where $A / W$ equals the concentration of albumin in the water of the serum in grams per liter, and $G / W$ equals

\section{TABLE I}

\section{Experimental data on control subjects}

The effective venous pressure in each instance was 20 $\mathrm{cm}$. above the colloid osmotic pressure of the serum. The cuff pressure actually applied, because of the vertical position of the plethysmograph, exceeded this figure by 19 to $24 \mathrm{~cm} . \mathrm{H}_{2} \mathrm{O}$.

\begin{tabular}{|c|c|c|c|c|c|c|c|c|c|}
\hline 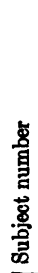 & 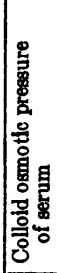 & 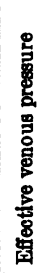 & 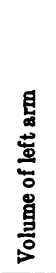 & 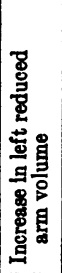 & 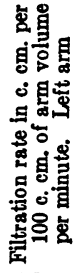 & 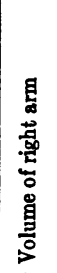 & 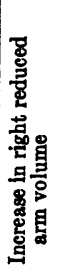 & 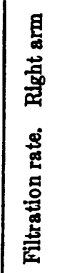 & $\begin{array}{l}\text { 要 } \\
\text { 总 } \\
\text { 总 }\end{array}$ \\
\hline & $\mathrm{Cm}_{2} \mathrm{O}$ & $\underset{\mathrm{H}}{\mathrm{Cm}} \mathrm{O}$ & c. cm. & c. cm. & & c. $\mathrm{cm}$. & c. cm. & & \\
\hline $\begin{array}{r}1 \\
2 \\
3 \\
4 \\
5 \\
6 \\
7 \\
8 \\
9 \\
10 \\
11 \\
12 \\
13\end{array}$ & \begin{tabular}{|l}
38.0 \\
40.3 \\
37.4 \\
30.7 \\
33.1 \\
26.3 \\
29.4 \\
35.6 \\
28.3 \\
34.4 \\
35.2 \\
31.0 \\
36.2
\end{tabular} & \begin{tabular}{|l}
58.0 \\
60.3 \\
57.4 \\
50.7 \\
53.1 \\
46.3 \\
49.4 \\
55.6 \\
48.3 \\
54.4 \\
55.2 \\
51.0 \\
56.2
\end{tabular} & $\begin{array}{l}\mathbf{5 5 0} \\
670 \\
470 \\
380 \\
375 \\
425 \\
400 \\
580 \\
430 \\
632 \\
675 \\
665 \\
425\end{array}$ & $\begin{array}{r}10.2 \\
8.7 \\
7.3 \\
5.3 \\
5.6 \\
6.5 \\
5.8 \\
5.9 \\
5.8 \\
9.7 \\
9.3 \\
8.0 \\
6.0\end{array}$ & $\begin{array}{l}0.185 \\
0.130 \\
0.155 \\
0.194 \\
0.149 \\
0.155 \\
0.145 \\
0.108 \\
0.155 \\
0.155 \\
0.140 \\
0.120 \\
0.140\end{array}$ & $\begin{array}{l}540 \\
690 \\
520 \\
380 \\
375 \\
460 \\
420 \\
\mathbf{5 9 0} \\
475 \\
632 \\
660 \\
680 \\
460\end{array}$ & $\begin{array}{r}10.4 \\
7.9 \\
7.8 \\
6.0 \\
6.0 \\
8.0 \\
6.1 \\
6.3 \\
7.1 \\
9.3 \\
11.0 \\
8.0 \\
6.2\end{array}$ & $\begin{array}{l}0.198 \\
0.115 \\
0.150 \\
0.168 \\
0.160 \\
0.178 \\
0.145 \\
0.107 \\
0.160 \\
0.147 \\
0.165 \\
0.118 \\
0.185\end{array}$ & $\begin{array}{l}\text { Normal } \\
\text { Normal } \\
\text { Normal } \\
\text { Normal } \\
\text { Normal } \\
\text { Normal } \\
\text { Normal } \\
\text { Normal } \\
\text { Normal } \\
\text { Normal } \\
\text { Normal } \\
\text { Normal } \\
\text { Normal }\end{array}$ \\
\hline $\begin{array}{l}35 \\
36 \\
36\end{array}$ & \begin{tabular}{|l|}
27.7 \\
34.8 \\
34.8
\end{tabular} & $\begin{array}{l}47.7 \\
54.8 \\
54.8\end{array}$ & $\begin{array}{l}605 \\
505 \\
505\end{array}$ & $\begin{array}{l}7.6 \\
6.3 \\
6.2\end{array}$ & $\begin{array}{l}0.125 \\
0.125 \\
0.123\end{array}$ & $\begin{array}{l}\mathbf{5 9 5} \\
\mathbf{5 1 0} \\
\mathbf{5 1 0}\end{array}$ & $\begin{array}{l}7.5 \\
6.3 \\
5.8\end{array}$ & $\begin{array}{l}0.125 \\
0.125 \\
0.114\end{array}$ & $\begin{array}{l}\text { Nephritis } \\
\text { Urticaria } \\
\text { Urticaria during }\end{array}$ \\
\hline 37 & 36.2 & 56.2 & 625 & 6.9 & 0.110 & 635 & 8.5 & 0.134 & Vitamin $\mathbf{C}$ in blood \\
\hline 37 & 36.2 & 56.2 & 625 & 6.5 & 0.104 & 635 & 6.7 & 0.105 & $\begin{array}{l}\text { Vitamin } C \text { in blood } \\
0.7 \mathrm{mgm} \text {. per cent }\end{array}$ \\
\hline
\end{tabular}


TABLE II

Experimental data on patients with liver disease

These readings are essentially similar to the control group.

\begin{tabular}{|c|c|c|c|c|c|c|c|c|c|}
\hline 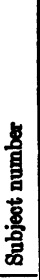 & 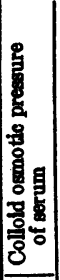 & 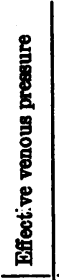 & 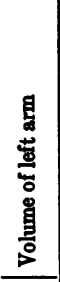 & 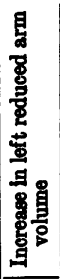 & 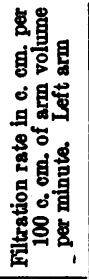 & 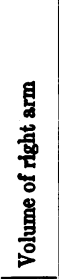 & 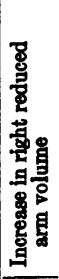 & 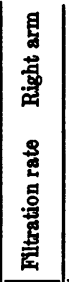 & $\begin{array}{l}\text { 罟 } \\
\text { 蒠 } \\
\text { 吕 }\end{array}$ \\
\hline & $\mathrm{Cm}_{2} \mathrm{O}$ & $\stackrel{c m}{\mathrm{H}_{2} \mathrm{O}}$ & c. cm. & c. cm. & & c.cm. & c. cm. & & \multirow{4}{*}{$\begin{array}{l}\text { Cirrhosis (toxio) } \\
\text { Cirrhosis (biliary) } \\
\text { (preop.) } \\
\text { Cirrhogis (postop.) } \\
\text { Cirrhosis (biliary) } \\
\text { (preop.) } \\
\text { Cirrhosis (postop.) } \\
\text { Yellow strophy } \\
\text { Cirrhosis (biliary) } \\
\text { Cirrhosis (biliary) } \\
\text { Cirrhodis (toxic) } \\
\text { Girrhosis (toxic) } \\
\text { Girhosis (toxic) } \\
\text { Cirrhods (toxic) }\end{array}$} \\
\hline $\begin{array}{l}14 \\
15\end{array}$ & \begin{tabular}{|l|}
23.6 \\
27.4
\end{tabular} & \begin{tabular}{|l|}
43.6 \\
47.4
\end{tabular} & $\begin{array}{l}520 \\
505\end{array}$ & $\begin{array}{l}6.7 \\
b .3\end{array}$ & $\begin{array}{l}0.130 \\
0.105\end{array}$ & $\begin{array}{l}520 \\
540\end{array}$ & $\begin{array}{l}7.5 \\
6.1\end{array}$ & $\begin{array}{l}0.144 \\
0.115\end{array}$ & \\
\hline $\begin{array}{l}15 \\
16\end{array}$ & $\begin{array}{l}27.4 \\
29.4\end{array}$ & $\begin{array}{l}47.4 \\
49.4\end{array}$ & $\begin{array}{l}505 \\
475\end{array}$ & $\begin{array}{l}4.8 \\
8.2\end{array}$ & $\begin{array}{l}0.095 \\
0.178\end{array}$ & $\begin{array}{l}520 \\
495\end{array}$ & $\begin{array}{l}5.9 \\
8.6\end{array}$ & $\mid$\begin{tabular}{l|}
0.119 \\
0.178
\end{tabular} & \\
\hline $\begin{array}{l}16 \\
17 \\
18 \\
19 \\
20 \\
21 \\
22 \\
23\end{array}$ & \begin{tabular}{|l|}
29.4 \\
20.0 \\
29.8 \\
32.3 \\
25.7 \\
23.2 \\
24.0 \\
24.3
\end{tabular} & $\begin{array}{l}49.4 \\
40.0 \\
49.8 \\
52.3 \\
45.7 \\
43.2 \\
44.0 \\
44.3\end{array}$ & $\begin{array}{l}475 \\
540 \\
375 \\
425 \\
570 \\
550 \\
400\end{array}$ & $\begin{array}{l}7.8 \\
7.9 \\
5.4 \\
7.0 \\
7.7 \\
7.2 \\
6.1\end{array}$ & $\begin{array}{l}0.164 \\
0.146 \\
0.145 \\
0.165 \\
0.195 \\
0.191 \\
0.150\end{array}$ & $\begin{array}{l}495 \\
540 \\
365 \\
430 \\
575 \\
560 \\
440 \\
575\end{array}$ & $\begin{array}{l}8.7 \\
7.7 \\
4.3 \\
8.3 \\
8.0 \\
7.0 \\
7.3 \\
5.3\end{array}$ & $\left|\begin{array}{l}0.175 \\
0.148 \\
0.118 \\
0.198 \\
0.139 \\
0.186 \\
0.165 \\
0.098\end{array}\right|$ & \\
\hline
\end{tabular}

the concentration of globulin in the water of the serum in grams per liter, the colloid osmotic pressure being expressed in millimeters of water. $W$ was calculated from the formula of Eisenmann, MacKenzie, and Peters (12).

$$
W=98.40-.718 \times \text { Serum total protein. }
$$

3. Preparation. The determinations were ordinarily made in the afternoon, commencing about one and onehalf hours after the noon meal. Ordinarily the left arm was measured first and the right arm one and one-half hours later. After therapy the left arms of Patients 32, 33 , and 34 were studied in the fasting state, as were the left arms of certain of the postoperative patients with thyrotoxicosis. Because of the possible significance of alterations in metabolism upon the rate of filtration, metabolic tests in the afternoon were made upon one subject (Number 24) and were compared with basal rates obtained on the same days. The afternoon rates were only 4 to 6 points higher than the morning rates.

4. Bilateral readings. With three exceptions necessitated by clinical exigency, all determinations were made on both arms. The readings of the two arms were recorded separately in the figures and tables.

5. Reduced arm volumes. Readings of reduced arm volume were commenced every 10 minutes, the pressure being applied for 2 minutes and released for 8 minutes. During the 2-minute period burette readings were made every 30 seconds, but only the final reading was used in comparing the successive periods. Readings of reduced arm volume were continued until the final readings of two successive periods checked within $1.0 \mathrm{cc}$. With women this usually required 5 to 6 readings, with men 6 to 8 readings. After a satisfactory check was obtained, the pressure was released and the brachial cuff

\section{TABLE III}

Experimental data on patients with thyrotoxicosis and on patients with myxedema

Note that although the bilateral readings usually checked moderately closely, there were great fluctuations in the rate from one therapeutic stage to another.

\begin{tabular}{|c|c|c|c|c|c|c|c|c|c|}
\hline \multirow[t]{2}{*}{ 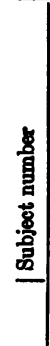 } & 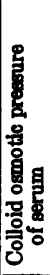 & 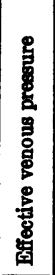 & 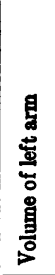 & 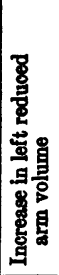 & 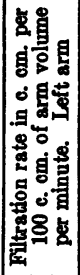 & 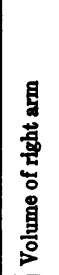 & 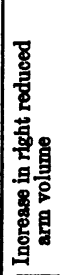 & 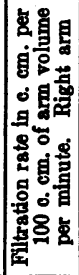 & 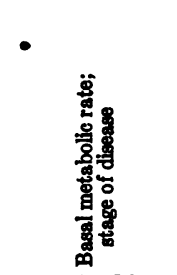 \\
\hline & $\mathrm{Cm}_{2} \mathrm{O}$ & $\underset{\mathrm{H}_{2} \mathrm{O}}{\mathrm{cm}}$ & c. $\mathrm{cm}$. & $c_{0} \mathrm{~cm}$. & & c. cm. & c.cm. & & per cent \\
\hline \multicolumn{10}{|c|}{ PATIENTS WITH THYROTOXICOSIS } \\
\hline $\begin{array}{l}24 \\
24\end{array}$ & $\begin{array}{l}31.5 \\
31.5\end{array}$ & $\begin{array}{l}51.5 \\
51.5\end{array}$ & $\begin{array}{l}540 \\
560\end{array}$ & $\begin{array}{l}8.6 \\
8.5\end{array}$ & $\begin{array}{l}0.159 \\
0.150\end{array}$ & $\begin{array}{l}560 \\
570\end{array}$ & $\begin{array}{l}9.3 \\
8.0\end{array}$ & $\begin{array}{l}0.165 \\
0.140\end{array}$ & $\begin{array}{l}+35(+41) \text { preop. } \\
+46(+52) \text { after }\end{array}$ \\
\hline $\begin{array}{l}24 \\
25 \\
25 \\
26 \\
26 \\
26 \\
27 \\
27 \\
27 \\
28 \\
28 \\
28 \\
29 \\
29 \\
29 \\
30 \\
30 \\
30 \\
31 \\
31 \\
31\end{array}$ & $\begin{array}{l}31.5 \\
31.8 \\
31.8 \\
30.0 \\
30.0 \\
30.0 \\
27.0 \\
27.0 \\
27.0 \\
30.3 \\
30.3 \\
30.3 \\
32.3 \\
32.3 \\
32.3 \\
33.5 \\
33.5 \\
33.5 \\
33.7 \\
33.7 \\
33.7\end{array}$ & $\begin{array}{l}51.5 \\
51.8 \\
51.8 \\
50.0 \\
50.0 \\
50.0 \\
47.0 \\
47.0 \\
47.0 \\
50.3 \\
50.3 \\
50.3 \\
552.3 \\
52.3 \\
52.3 \\
53.5 \\
55.5 \\
55.5 \\
53.7 \\
53.7 \\
53.7\end{array}$ & $\begin{array}{l}570 \\
680 \\
575 \\
445 \\
475 \\
370 \\
370 \\
425 \\
410 \\
410 \\
510 \\
455 \\
455 \\
550 \\
430 \\
440 \\
405 \\
403 \\
440\end{array}$ & $\begin{array}{l}6.2 \\
8.5 \\
6.2 \\
7.6 \\
5.5 \\
5.7 \\
7.2 \\
4.5 \\
7.1 \\
5.9 \\
5.6 \\
5.6 \\
7.0 \\
5.9 \\
6.5 \\
6.2 \\
4.7 \\
5.1 \\
7.7\end{array}$ & $\begin{array}{l}0.109 \\
0.185 \\
0.105 \\
0.170 \\
0.115 \\
0.156 \\
0.195 \\
0.105 \\
0.175 \\
0.140 \\
0.110 \\
0.128 \\
0.164 \\
0.107 \\
0.160 \\
0.140 \\
0.116 \\
0.185 \\
0.175\end{array}$ & $\begin{array}{l}580 \\
680 \\
600 \\
475 \\
495 \\
495 \\
370 \\
370 \\
425 \\
395 \\
422 \\
525 \\
465 \\
465 \\
570 \\
440 \\
445 \\
478 \\
455 \\
400 \\
484\end{array}$ & $\begin{array}{r}6.3 \\
10.2 \\
6.7 \\
9.5 \\
7.5 \\
7.3 \\
5.8 \\
7.0 \\
6.0 \\
7.2 \\
5.7 \\
5.9 \\
7.2 \\
7.7 \\
6.9 \\
6.6 \\
6.7 \\
6.5 \\
5.4 \\
4.3 \\
7.8\end{array}$ & $\begin{array}{l}0.109 \\
0.150 \\
0.110 \\
0.800 \\
0.150 \\
0.148 \\
0.165 \\
0.190 \\
0.140 \\
0.180 \\
0.195 \\
0.118 \\
0.165 \\
0.165 \\
0.181 \\
0.150 \\
0.150 \\
0.156 \\
0.119 \\
0.108 \\
0.168\end{array}$ & $\begin{array}{l}-13 \text { (-9) postop. } \\
+17 \text { preop. } \\
+12 \text { postop. } \\
+23 \text { preop. } \\
+23 \text { after iodine } \\
+9 \text { postop. } \\
+46 \text { preop. } \\
+10 \text { after iodine } \\
+1 \text { postop. } \\
+49 \text { preop. } \\
+26 \text { after iodine } \\
+3 \text { postop. } \\
+33 \text { preop } \\
+21 \text { after iodine } \\
-12 \text { postop. } \\
+34 \text { preop. } \\
+15 \text { after iodine } \\
\text { +1 postop. } \\
+18 \text { preop. } \\
+50 \text { after iodine } \\
-15 \text { postop. }\end{array}$ \\
\hline
\end{tabular}

PATIENTS WITH MTTXIDNM

\begin{tabular}{l|l|l|l|l|l|l|r|l|l}
\hline 32 & 38.7 & 58.7 & 700 & 7.4 & 0.105 & 700 & 7.4 & 0.105 & -50 \\
32 & & & 575 & 8.6 & 0.160 & 600 & 9.6 & 0.160 & +8 after treatment \\
33 & 41.5 & 61.5 & 600 & 7.6 & 0.187 & 600 & 7.6 & 0.187 & -35 \\
33 & 39.6 & 59.6 & 500 & 8.1 & 0.160 & 550 & 10.3 & 0.186 & +13 after treatment \\
34 & 39.6 & 6.5 & 0.185 & 520 & 6.3 & 0.181 & -38 \\
34 & & & 435 & 6.6 & 0.160 & 440 & 8.0 & 0.180 & -11 after treatment \\
\hline
\end{tabular}

was inflated for a period of 10 minutes. At the end of this time, it was deflated and 3 seconds later the final reading was commenced.

6. Determination of arm volume. The two ends of the segment of forearm which had been in the plethysmograph were encircled with a skin pencil. Transient marks from the diaphragms of the plethysmograph facilitated this procedure. By immersion in and displacement of fluid from a narrow necked vessel, the amount of arm volume actually in the plethysmograph was estimated. From this figure and the increase in reduced arm volume the rate of filtration was readily calculated.

\section{OBSERVATIONS}

All the significant determinations are recorded in Tables I, II, and III. In each instance the calculated colloid osmotic pressure of the serum and the obstructing venous pressure effective 
within the plethysmograph were identical for the two arms. However, the volume of each arm and the increase in reduced arm volume of each arm are recorded separately, so that the accuracy of the checks from one arm to the other may readily be observed. The final filtration rates are recorded separately for each arm both in Tables I, II, and III and in Figures 1 and 2 where they are represented in purely graphic form.

In Figure 1 are recorded the observations upon the control group and the group of patients with liver disease. Included in the control group are three patients with non-hepatic diseases. The diagnoses of the patients suffering from diseases of the liver are noted in Table II. Both groups were partitioned on the basis of sex, and this differentiation is shown in Figure 1, from a study of which it is apparent that the observed rate of filtration was higher in the females than in the males. The limits of normal observed in the control groups were not exceeded in the liver disease groups. In fact, the upper and lower limits observed in female controls and female patients with liver disease were almost identical, as were those observed in the male groups.

At $35^{\circ} \mathrm{C}$. the rates in all subjects varied from 0.092 to $0.200 \mathrm{cc}$. per $100 \mathrm{cc}$. of arm volume in 1 minute. In two healthy adults (males) at a plethysmograph temperature between $34.0^{\circ}$ and $35.0^{\circ} \mathrm{C}$. and at an effective venous pressure of $50 \mathrm{~cm} . \mathrm{H}_{2} \mathrm{O}$, Landis and Gibbon found the filtration rate to vary from 0.114 to 0.153 with a mean of 0.128 . This figure corresponds closely with the mean figures obtained in this study in male control subjects and male patients with liver disease ( 0.125 and 0.121 respectively).

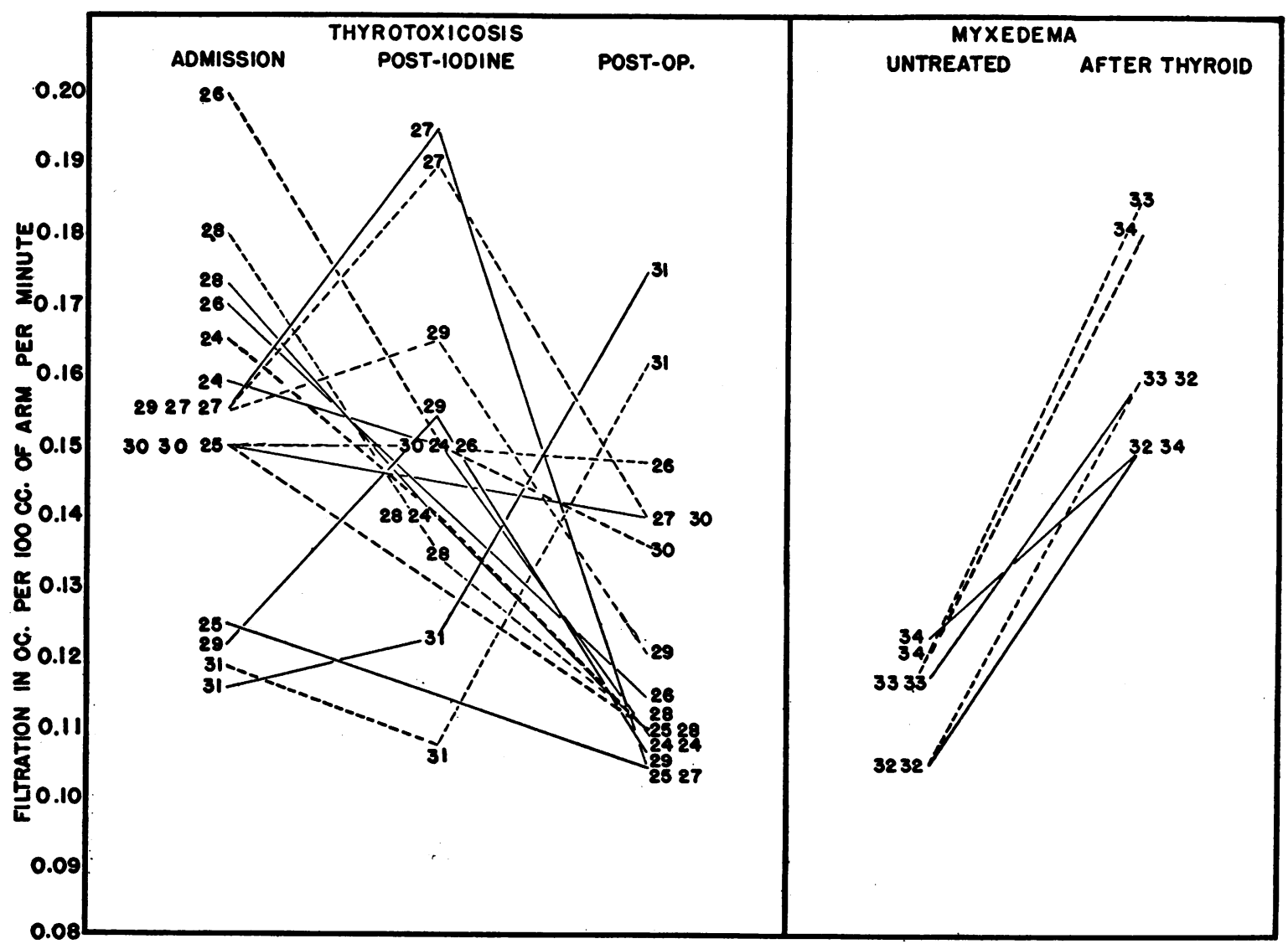

Fig. 2. Rates of Filtration in Various Therapeutic Stages of Thyrotoxicosis and Myxedema

Broken lines connect right arm readings, solid lines connect left arm readings. Note that in thyrotoxicosis there are wide fluctuations in the rate of filtration with a tendency to a reduction in rate after operative treatment. In myxedema there is a sharp increase in rate after thyroid therapy. 
In Table III and Figure 2 are recorded the changes observed in patients with metabolic disorders who were followed through different stages in their metabolic levels. Patients with thyrotoxicosis tended to show rates with variations in the upper range of normal before the institution of therapy. In most instances the rate of filtration fell slightly after iodine preparation and fell somewhat more after subtotal thyroidectomy. The average rate during the active disease was 0.153 , after iodine therapy 0.150 , and after operation, 0.125 cc. per 100 cc. of arm volume per minute. There were, however, certain very striking exceptions to this observation. These are discussed elsewhere. Basal metabolic rates obtained during each metabolic stage are tabulated in Table III.

Patients with myxedema showed extremely low rates of filtration before treatment with thyroid preparations and much higher rates after their basal metabolic rates had been restored to normal. The average rate before treatment was 0.118 and the average rate after treatment was $0.164 \mathrm{cc}$. per $100 \mathrm{cc}$. of arm volume per minute. The increase was in each case accompanied by an acute drop in arm volume, a factor which is discussed below. The basal metabolic rates before and after treatment are shown in Table III, and the changes in filtration rate are graphically recorded in Figure 2.

\section{DISCUSSION}

That no patients in any of the pathological groups showed filtration rates in excess of the normal conforms with reasonable expectation. Beecher (13) emphasized that in normal persons tissue fluid was constantly being formed in the dependent extremities owing to the presence of a hydrostatic column far greater in height than the colloid osmotic pressure of the serum. Hence the lymphatic system, at best, is under a constant strain to remove tissue fluid fast enough to prevent edema formation. In view of this fact it would seem likely that any generalized increase in permeability of the capillary vessels would result in almost immediate edema formation. Although some of the patients with liver disease did have edema, they also had a depleted serum albumin. When the resultant decrease in colloid osmotic pressure was taken into account, the plethysmograph revealed no increase in rate of tissue fluid formation. That there was a distinctly higher rate of filtration in women than in men is apparent. It at first seemed likely that this was a function inversely proportional to arm volume, but an attempt to correlate the two factors was inconsistent. It is probable that the rate of filtration in women is actually greater and that arm volume is not the only factor involved. The highest rate observed in a control subject was in Subject 1. This woman suffered from frank edema at the time of her menstrual periods, but was free from it at other times. Her edema is associated with a definite weight gain during menstruation.

The identical ranges of filtration rates which were observed in patients with liver disease and in the control groups presumably constitute a significant negative finding. The rates for male patients corresponded with those found in male controls and the rates for female patients corresponded with those of female controls. So far as is known, there were no gross alterations in the oxygen consumption of the patients with liver disease. The alterations in colloid osmotic pressure of the serum were controlled. Hence it is felt that the negative finding is a true one and that it may be concluded that the permeability of the capillary walls in intrinsic diseases of the liver is unaltered. It may not be concluded, however, that the fragility of the walls is unaltered. There is apparently a difference between permeability to the passage of fluid and fragility to trauma.

In contrast to the rather well controlled observations on liver disease, there were uncontrollable factors in the study of the metabolic diseases. Although the plethysmograph pressure collapses the entire vascular tree during the reading of reduced arm volume, plethysmograph temperature is the only control of the dilation of the capillary bed during the 10-minute period of filtration. Landis and Gibbon demonstrated that alterations in the temperature of the plethysmograph were accompanied by gross proportional alterations in the rate of filtration. Hudack and McMaster (14) showed that in the rabbit's ear extravasation of dye took place much more readily if the blood vessels were generally dilated following the administration of heat. Roberts and Griffith 
(15), by the technique of comparing the number of capillary tufts in an area of skin with the number observed in the same area after the nearby injection of histamine, concluded that in thyrotoxicosis the capillary bed was widely dilated. Shaw (16) measured the rate of blood flow in the arm in thyrotoxicosis by the use of the plethysmograph of Freeman, Shaw, and Snyder (17). Shaw made observations on patients with thyrotoxicosis before operation, after preparation with iodine, and one month or more following operation. He found in the majority of cases that the blood flow was most rapid during the toxic process, became less so following the administration of iodine and still less so after operation. However, as in the case of the rate of flow through the capillary walls, he found several notable exceptions in which the rate of blood flow increased following the administration of iodine. These observations roughly coincided with the changes which were noted in the rate of filtration through the capillary walls. It may be that the changes in filtration rate are directly dependent upon the degree of dilation of the capillary bed during the period of filtration. Wide dilation of the capillary bed produces an increase in the available surface of capillary endothelium and it may be that the increase in filtration rate observed in hyperthyroidism is dependent upon this factor rather than upon a specific change in the permeability of the capillary endothelium. This question cannot be answered by the pressure plethysmograph alone.

With regard to patients with myxedema at least two more uncontrolled factors are involved. After the myxedematous patients had been treated, their arm volumes became much smaller than previously, presumably because of diminution in the amount of edema. Landis and Gibbon showed that the rate of filtration depended in part upon tissue resistance. They showed that the presence of large amounts of tissue fluid slowed down the rate of filtration. Hence the slow rate of myxedema may be in part owing to increased tissue resistance from the viscid myxedema fluid. Another uncontrolled factor is the possibility of sudden changes in the level of serum albumin or globulin. The total protein level of patients with clinical myxedema was extremely high; and a high obstructing venous pressure was applied to offset it. Unfortunately, the protein levels were not repeated after treatment, so that sudden falls in protein levels might have resulted in the use of an unjustifiably high obstructing venous pressure.

Whatever the underlying mechanism, there were very dramatic changes in the rate of filtration through the capillary walls of patients with hyperthyroidism and with myxedema at different basal metabolic levels. The close parallelism of the readings of the right and left arms confirms the significance of these changes.

\section{CONCLUSIONS}

1. In given individuals, repeated determinations of the rate of flow of fluid through the capillary walls could be checked with a reasonable degree of accuracy. The method is, therefore, readily applicable to studies where changes associated with other physiological variations in the same person are important.

2. At $35^{\circ} \mathrm{C}$. the range of readings observed in normal controls was very wide and was not significantly exceeded in any of the pathological states studied.

3. The rates of filtration observed in patients with three different types of intrahepatic disease fell within the normal limits for their respective sexes. It is reasonable to conclude that abnormal accumulations of fluid in the tissue and serous cavities in liver disease is in no way dependent on alterations in capillary permeability.

4. Metabolic changes grossly affected the rate of flow of fluid through the capillary walls. Various mechanisms which may explain this phenomenon are discussed. The factor of oxygen consumption should be controlled in subsequent studies.

\section{BIBLIOGRAPHY}

1. Cutter, I. S., and Marquart, G. H., Studies on capillary fragility. Proc. Soc. Exper. Biol. and Med., 1930, 28, 113.

2. Cutter, I. S. and Johnson, C. A., Studies on capillary fragility: a device for the study of capillary hemorrhage. J. A. M. A., 1935, 105, 505.

3. Peterson, W. F., The permeability of the skin capillaries in various clinical conditions. Arch. Int. Med., 1927, 39, 19.

4. Landis, E. M., Microinjection studies of capillary permeabilty. I. Factors in the production of capillary stasis. Am. J. Physiol., 1927, 81, 124. 
Landis, E. M., Microinjection studies of capillary permeability. II. The relation between capillary pressure and the rate at which fluid passes through the walls of single capillaries. Am. J. Physiol., 1927, 82, 217.

Landis, E. M., Microinjection studies of capillary permeability. III. The effect of lack of oxygen on the permeability of the capillary wall to fluid and to the plasma proteins. Am. J. Physiol., 1928, 83, 528.

5. Landis, E. M. and Gibbon, J. H., The effects of temperature and of tissue pressure on the movement of fluid through the human capillary wall. J. Clin. Invest., 1933, 12, 105.

6. Krogh, A., Landis, E. M. and Turner, A. H., The movement of fluid through the human capillary wall in relation to venous pressure and to the colloid osmotic pressure of the blood. J. Clin. Invest., 1932, 11, 63.

7. Smirk, S. H., Observations on the capillary permeability in cases of nephritis and of hepatic cirrhosis with hypoproteinaemia. Clin. Sc., 1935, 2 , 57.

8. Verney, E. B., The osmotic pressure of the proteins of human serum and plasma. J. Physiol., 1926, $61,319$.

9. Starling, E. H., The Fluids of the Body. The Herter Lectures New York, 1908. W. T. Keener and Co., Chicago, 1909.

10. Govaerts, P., Influence de la teneur du sérum en albumines et en globulines sur la pression osmotique des protéines et sur la formation des oedemes. Bull. Acad. roy. de méd. de Belgique, 1927, 7, 356.

11. Wies, C. H. and Peters, J. P., The osmotic pressure of proteins in whole serum. J. Clin. Invest., 1937, 16, 93.

12. Eisenmann, A. J., MacKenzie, L .R. and Peters, J. P., Protein and water of serum and cells of human blood. J. Biol. Chem., 1936, 116, 33.

13. Beecher, H. K., Adjustment af the flow of tissue fluid in the presence of localized sustained high venous pressure as found with varices of the great saphenous system during walking. J. Clin. Invest., 1937, 16, 733.

14. Hudack, S. and McMaster, D. D., The gradient of permeability of the skin vessels as influenced by heat, cold and light. J. Exper. Med., 1932, 55, 431.

15. Roberts, E. and Griffith, J. Q., Jr., Quantitative study of cutaneous capillaries in hyperthyroidism. Am. Heart J., 1937, 14, 598.

16. Shaw, J. L., The volume of blood flow through the hand in relation to the basal metabolic rate. (To be published.)

17. Freeman, N. E., Shaw, J. L., and Snyder, J. C., The peripheral blood flow in surgical shock. The reduction in circulation through the hand resulting from pain, fear, cold and asphyxia with quantitative measurements of the volume flow of blood in clinical cases of surgical shock. J. Clin. Invest., $1936,15,651$. 